\title{
Goethe's Archaeology of the Modern Curse (Orest, Faust, Manfred)
}

Berndt, Frauke ; Meixner, Sebastian ; Mahler, Anthony

DOI: https://doi.org/10.1353/mln.2016.0041

Posted at the Zurich Open Repository and Archive, University of Zurich ZORA URL: https://doi.org/10.5167/uzh-159263

Journal Article

Accepted Version

Originally published at:

Berndt, Frauke; Meixner, Sebastian; Mahler, Anthony (2016). Goethe's Archaeology of the Modern Curse (Orest, Faust, Manfred). MLN (Modern language notes), 131(3):601-629.

DOI: https://doi.org/10.1353/mln.2016.0041 


\section{PROJECT MUSE*}

Goethe's Archaeology of the Modern Curse (Orest, Faust, Manfred)

Frauke Berndt, Sebastian Meixner, Anthony Mahler

MLN, Volume 131, Number 3, April 2016 (German Issue), pp. 601-629 (Article)

Published by Johns Hopkins University Press

DOI: https://doi.org/10.1353/mln.2016.0041

$\Rightarrow$ For additional information about this article https://muse.jhu.edu/article/632257 


\section{Goethe's Archaeology of the Modern Curse (Orest, Faust, Manfred)}

\section{జ \\ Frauke Berndt \& Sebastian Meixner}

Today the curse has disappeared from epistemological memory. We curse people and things without an institution that would guarantee its success. Because of this, curses also cannot fail; instead, they have degenerated into profanities and insults. The curse has become historical. The current interdisciplinary ensemble of cultural studies has explored an archaeology of the curse based on speech-act theory. ${ }^{1}$ In this context, there has primarily been an interest in pre-modern literature and especially for Shakespeare's royal dramas, in which the institutions of the curse serve as the background. ${ }^{2}$ But even Johann Wolfgang Goethe-the Enlightenment humanist and classicist—can impart significant insights into the archaeology of the curse since his dramas show how the institutions constitutive of the curse have changed. After (I) elucidating the theoretical background of the curse, we will describe (II) the paradigmatic structures of the curse in Iphigenie auf Tauris: Ein Schauspiel (1787) and (III) its syntagmatic variations in both Faust: Eine Tragödie (1808) and Goethe's partial translation (1823) of Lord Byron's Manfred: A Dramatic Poem (1817).

${ }^{1}$ Friedrich, Peter and Schneider, Manfred. "Einleitung: "Sprechkrafttheorien" oder Eid und Fluch zwischen Recht, Sprachwissenschaft, Literatur und Philosophie." Fatale Sprachen: Eid und Fluch in Literatur- und Rechtsgeschichte. Ed. Peter Friedrich and Manfred Schneider. Munich: Wilhelm Fink, 2009: 7-19.

${ }^{2}$ Quiring, Björn. Shakespeares Fluch: Die Aporien ritueller Exklusion im Königsdrama der englischen Renaissance. Munich: Wilhelm Fink, 2009. 


\section{Theories of the curse}

The Handwörterbuch des deutschen Aberglaubens notes: "Fluch ist eine Redeformel, durch welche man Unheil auf einen anderen oder auf dessen Habe oder auch auf sich selbst herabwünscht." ${ }^{3}$ Such imprecations are based on a "magical worldview" in which words become or can become actions. ${ }^{4}$ This definition presupposes a model of communication that takes the curse, cursers, and accursed into account; it coincides with a model of communication that is also foundational for analyzing drama, so a methodological perspective already suggests a continuity between the curse and drama. And there is cursing in dramas; for this reason, drama is in a position to impart insights into the economy of curses and cursing. Drama reacts to "real" cursing by constantly observing and reflecting on it. Expressed differently, dramatic curses are second-order curses, and so they always have a dramaturgical and poetological dimension.

On the basis of communication theory, the curse is assigned two semantic roles: the curser takes on the role of the grammatical agent and the accursed that of the grammatical patient. ${ }^{5}$ In cultural studies, the two are problematically called the perpetrator and the victim, which presupposes a moral valuation. In contrast, Maximilian Oettinger refers to the curser as the victim and the accursed as the perpetrator. The curse would then be the ultima ratio defense after all other legal means have been exhausted, allowing the powerless victim to make a stand against suffered injustices and, at least to some extent, to regain agency. The curse is also the highest punishment and most powerful weapon. Because of the affectivity that such a communicative situation creates, the curse veers into the vicinity of revenge. ${ }^{6}$

But the perpetrator-victim model can just as legitimately be reversed. The curser is the perpetrator who expels the victim from the social community, because the victim has committed a wrong. Either this expulsion is connected to a violation against the world order, so that the curse repels a threat to the community from within, or the curse

${ }^{3}$ Beth, K. "Fluch." Handwörterbuch des deutschen Aberglaubens. Ed. Hanns BächtoldStäubli. Vol. 2. Berlin, Leipzig: Weltbild, 2000: 1636-52, here 1636.

${ }^{4}$ Beth. Fluch: 1637. All translations by Anthony Mahler unless otherwise noted.

${ }^{5}$ Grewendorf, Günther, Fritz Hamm, and Wolfgang Sternefeld. Sprachliches Wissen: Eine Einführung in moderne Theorien der grammatischen Beschreibung. Frankfurt am Main: Suhrkamp, 1987: 190.

${ }^{6}$ Oettinger, Maximilan. Der Fluch:Vernichtende Rede in sakralen Gesellschaften der jüdischen und christlichen Tradition. Konstanz: Hartung-Gorre, 2007: 2-5; Vedder, Ulrike. "Der Fluch als Schuld und Übertragung." Bonds: Schuld, Schulden und andere Verbindlichkeiten. Ed. Thomas Macho. Munich: Wilhelm Fink, 2014: 509-20, here 514. 
blindsides the victim because the perpetrator represents the "Other" of the community, as in fairy tales where the perpetrator is usually an "evil" that threatens the community from the outside. In brief, the perpetrator-victim model relies on a moral or judicial valuation of the situation, while the formal model of semantic roles starts with the curse itself and makes attributions based on its structure.

In any case, both models presuppose an institution that makes the curse a curse. This institution must be recognized within the community from which the accursed is excluded and into which the curser is included. This institution is ordinarily represented by gods, a god, or other higher powers that support the curse and ensure its enforcement. ${ }^{7}$ Such institutions must be absolute institutions for those that are cursed-they are a matter of faith. The concept of performativity mediates between the speech act and the institution, a performativity which Judith Butler has defined by three aspects: anticipation, repetition, and ritualization. ${ }^{8}$ Martin Hagemeier has transferred these three aspects to Cornelius Castoriadis's concept of the institution. ${ }^{9}$ In its enforcement, one can assume that the curse institutionalizes a public sphere of performance; ${ }^{10}$ in other words, without the institution-and this should be stressed-there is no curse.

The claim that the curse prescribes semantic roles is mirrored in all attempts to classify it linguistically as a Redeformel or formulaic language, such as in the Handwörterbuch des deutschen Aberglaubens. In the Deutsches Wörterbuch von Jacob und Wilhelm Grimm, one thus finds performatives in the entry on $f l u c h$, which directly refers to the corresponding figures of thought (figurae sententiae) in rhetoric: " $m$. exsecratio, imprecatio, maledictum, ahd. fluoch, mhd. vluoch, alts. fluoc, nd. flok, nnl. vloek. mangelt goth. ags. engl. altn. schw. dän., worüber mehr beim verbum. man sagt ein schwerer, harter, bitterer, tiefer, herzlicher fluch und dem fluch, der verwünschung steht der wunsch, der segen, dem verwünschen, devovere das wünschen, vovere gegenüber". ${ }^{11}$ Not only does the entry refer to the form of the curse; it also draws connections

${ }^{7}$ Dorschel, Andreas. "Entwurf einer Theorie des Fluchens." Variations 23 (2015): 167-75, here 167 .

${ }^{8}$ Butler, Judith. Gender Trouble: Feminism and the Subversion of Identity. New York and London: Routledge, 1999: xiv-xv.

${ }^{9}$ Hagemeier, Martin. Dem Chaos eine Form geben: Eine Einführung zu Cornelius Castoriadis. Norderstedt: Books on Demand, 2014: 152.

${ }^{10}$ Tucker, Kenneth. "From the Imaginary to Subjectivation: Castoriadis and Touraine on the Performative Public Sphere." Thesis Eleven 83 (2005): 42-60.

${ }^{11}$ Grimm, Jakob and Wilhelm Grimm. Deutsches Wörterbuch. Vol. 3. Leipzig: Hirzel, 1854-1961, p. 1827. 
between the curse and the wish, on the one hand, and the curse and the blessing, on the other.

On the basis of its linguistic form, eighteenth-century rhetoric understands the curse (exsecratio), as Dietmar Till points out, as a special form of apostrophe. ${ }^{12}$ For apostrophe is the figure of thought that has been employed within the system of rhetoric since antiquity to discuss the performativity of figures of thought in general. This is because apostrophe is the figure of interruption in communication. In drama, one describes it as a form of aversio that shifts the perspective of the communicative situation with regard to sender, message, and receiver. In this shift, aversio indicates a change of addressee: a dramatic character turns away from the other dramatis personae and toward a different addressee who is not located on the level of the internal communication system and is usually the audience on the level of the external communication system. ${ }^{13} \mathrm{~A}$ triadic structure thus underlies the dramaturgy of the curse.

But this dramaturgical analysis does not do justice to the actual logic of apostrophe, which Jonathan Culler characterizes as follows: "[I]t makes its point by troping not on the meaning of a word but on the circuit or situation of communication itself." ${ }^{14}$ The figure thus switches from representation to presence: "Apostrophe is not the representation of an event; if it works it produces a fictive, discursive event." ${ }^{15}$ And apostrophe itself becomes an institution exactly through this "power of poetry to make something happen." ${ }^{16}$ From this it follows that, as an apostrophe, the curse presupposes a triangular structure in which the speaker turns away from what is immediately opposite and turns toward the institution that guarantees the fulfillment of the curse and is even often named within the curse itself.

The institutional form of the curse, which rhetoric presupposes, is lost in the theories currently applied to the curse, especially in speechact theory. In How to Do Things with Words, J. L. Austin differentiates between locution, illocution, and perlocution. While locution simply

\footnotetext{
${ }^{12}$ Till, Dietmar. "Exsecratio." Historisches Wörterbuch der Rhetorik. Ed. Gert Ueding and Walter Jens. Vol. 3. Darmstadt: Wissenschaftliche Buchgesellschaft, 1996: 181-83.

${ }^{13}$ Pfister, Manfred. Das Drama. 11th ed. Munich: Wilhelm Fink, 2001: 20-22.

${ }^{14}$ Culler, Jonathan. "Apostrophe." Diacritics 7 (1977): 59-69, here 59; Meixner, Sebastian. "Die Notwendigkeit der Apostrophe: Metaleptische Strukturen in Johann Wolfgang Goethes 'Die Leiden des jungen Werthers.'” Ästhetik des Zufalls: Ordnungen des Unvorhersehbaren in Literatur und Theorie. Ed. Christoph Pflaumbaum, Carolin Rocks, Christian Schmitt and Stefan Tetzlaff. Heidelberg: Universitätsverlag Winter, 2015: $121-37$.

${ }^{15}$ Culler. Apostrophe: 68.

${ }^{16}$ Culler. Apostrophe: 62.
} 
refers to the utterance, illocution describes a conventional orientation of this act, and perlocution traces the effects of the act on the world. The curse connects illocution and perlocution like almost no other speech act. In his last lecture, Austin categorizes the curse within what he calls "behabitive" illocutionary speech acts, which announce a reaction to the behavior of others. From this perspective, the curse refers less to the accursed and more to the curser, because it constitutes the posture of the curser with regard to the accursed.

According to Austin, the curse is thus a negative form of a wish that is at first entirely independent of whether or not the content of the curse will come to pass, that is, whether or not it will be fulfilled. ${ }^{17}$ Although the curse therefore plays merely a subordinate role in current speech-act theories, ${ }^{18}$ it releases a performative force with enormous consequences for both the curser and the accursed, and-as the fairy tale again teaches us-it usually cannot be taken back, but rather only redirected or mitigated. If a curse is successful, then it is certainly one of the most powerful illocutionary acts since it entails immediate effects as a perlocutionary act. Exactly in the sense of Austin's "doing something by saying something," the grammatical patient is immediately under a curse: he or she is accursed as soon as the curse is expressed. ${ }^{19}$

Giorgio Agamben investigates this force of the curse in The Sacrament of Language: An Archaeology of the Oath, a volume in his homo sacer project. In contrast to the Handwörterbuch des deutschen Aberglaubens, Agamben argues that the curse cannot be explained using the paradigm of the "magico-religious." ${ }^{20}$ On the contrary, it is the oath (and with it the curse) "as originary performative experience of the word, that can explain religion [...]." ${ }^{21}$ Accordingly, Agamben questions the "immanent function" of the curse and thereby returns to its linguistic form, which he also recognizes, following the rhetorical tradition, as an apostrophe. ${ }^{22}$ At the same time, he directly connects the curse with its opposite, the blessing (sacratio), a connection which the Deutsches

\footnotetext{
${ }^{17}$ Austin, John. How to do things with Words. The William James Lectures delivered at Harvard University in 1955. Oxford: Oxford University Press, 1962: 149-51 and 159-60.

${ }^{18}$ The oath, however, is prominent in Charles Sanders Peirce, a forerunner of speech-act theory. Martens, Ekkehard. Texte der Philosophie des Pragmatismus. Stuttgart: Reclam, 1975: 8.

${ }^{19}$ Hermanns, Fritz: "Sprechkrafttheorie: $\mathrm{Zu}$ einem Fall von Sprachmagie in der Sprachwissenschaft." Grazer linguistische Studien 23 (1985): 35-63.

${ }^{20}$ Agamben, Giorgio. The Sacrament of Language: An Archaeology of the Oath. Stanford: Stanford University Press, 2011: 35.

${ }^{21}$ Agamben. The Sacrament of Language: 65.

${ }^{22}$ Agamben. The Sacrament of Language: 36.
} 
Wörterbuch etymologically verifies. ${ }^{23}$ This "twofold form" of the curse connects it to homo sacer, ${ }^{24}$ who is also doubly excluded: from divine law since homo sacer may not be sacrificed, and from human law since homo sacer may be killed without punishment. ${ }^{25}$ While we have emphasized the institution that guarantees the curse, Agamben literally gives this institution a name. From the immanent perspective of the speech act, the name of the institution to which the speaker appeals-for example, the name of a god-obtains a "double valence." ${ }^{26}$ The name is both benedictive and maledictive and lends the curse its performative force. It accomplishes this through "a suspension of the normal denotative character of language. ${ }^{27}$

In this way, the pragmatic status of the utterance changes in the curse, and with it the situation of the speaking subject changes. This is because the speaking subject "puts itself in play as such by linking itself performatively to the truth of its own affirmation." ${ }^{28}$ Agamben only explicitly explains this force of language in the case of the oath. As much as it makes sense that the speakers of oaths risk themselves due to the potential of perjury, this must certainly be even more true of the curse. In this sense, the curse surpasses the oath since the curse not only guarantees the truth content of the utterance, but also because the curser places himself in relation to a world order. Through its normative force, the curse determines the future of the accursed and thereby changes the present. In the sacrament of language realized by the curse, the speaking subject is thus always both the subject and object of the world order, which brings, to build on Agamben, the self-reflectivity of the curse into view. The following investigations show that literary works, and particularly Goethe's dramas, are the privileged site for reflecting on the conditions that make the curse possible. Goethe stages the curse in literature. By diminishing its force or strategically deploying it again and again, such enactments display the secularization of the curse in modernity. ${ }^{29}$ Yet they also show how this force remains effective due to the displacement of the institution of the curse from the "world" into the subject. There, namely in the subject, the curse unleashes its power. ${ }^{30}$

\footnotetext{
${ }^{23}$ Agamben, Giorgio. Homo sacer: Sovereign Power and Bare Life. Trans Daniel HellerRoazan. Stanford: Stanford University Press, 1988: 81-86.

${ }^{24}$ Agamben. The Sacrament of Language: 36.

${ }^{25}$ Agamben. Homo sacer: 81-82.

${ }^{26}$ Agamben. The Sacrament of Language: 38.

${ }^{27}$ Agamben. The Sacrament of Language: 55.

${ }^{28}$ Agamben. The Sacrament of Language: 57.

${ }^{29}$ Friedrich and Schneider. Einleitung: 9.

${ }^{30}$ Iphigenie auf Tauris and Faust: Eine Tragödie belong to the works of world literature that have produced an enormous amount of secondary literature. In this essay, we only refer to the scholarship that deals with the forms and functions of cursing.
} 


\section{Paradigmatic structure: Orest}

From a structural perspective, two dramatic plots come together in Iphigenie auf Tauris: the plot of Iphigenie and that of Orest. The two react to one another like a dialogue between the old and the new worlds. On the basis of this epic arrangement, Goethe cannot label the drama as a tragedy or a Trauerspiel, and instead simply titles it "Ein Schauspiel"-one could also call it a Beobachtungsspiel (that is, instead of a "play for looking at," roughly a spectacle, it is a "play of observation"). The curse of the House of Atreus and Tantalus-which means not just any curse, but rather the "mother of all curses"- serves as the fulcrum of observation. ${ }^{31}$ The great anathema of antiquity, which the gods imposed on Tantalus, forces his descendants to become murderers and victims of their own family members. According to Theodor W. Adorno, who follows the path of Arthur Henkel's interpretation, the myth constitutes the central issue of the play, which does not stage classical humanity, but the dialectic of civilization. The supposed Bildungsdrama turns out to be a Zivilisationsdrama. ${ }^{32}$ In the horizon of practical philosophy, the play deals with acknowledgment (Anerkennung). ${ }^{33}$ While Orest is introduced as a primitive character entirely subject to this curse and the world order it has established, Iphigenie has-"verteufelt human" as she is constructed (Schiller 39.1: 175) ${ }^{34}$ freed herself from the curse and its world order. Orest, the accursed heteronomous subject, is thus the opposite of Iphigenie, the no longer cursed autonomous subject. In this respect, Iphigenie auf Tauris serves as propaganda for secularization and qualifies as a central drama of nascent modernity. Iphigenie's "unerhörte Tat" (Goethe, FA 565, line $377)^{35}$ of parrhesia-how she, the beautiful Greek, defies the barbaric

\footnotetext{
${ }^{31}$ Staiger, Emil. Goethe. Vol 1. Zurich: Atlantis, 1952; Reed, Terence James. "Iphigenie auf Tauris." Goethe-Handbuch. Ed. Bernd Witte et al. Vol. 2. Stuttgart: Metzler, 2004: 195-208, here 195; Mandelartz, Michael. "Die 'reine Seele' und die Politik: Partikularität und Universalität in Goethes Iphigenie". Goethe Yearbook 16 (2009): 47-68.

${ }^{32}$ Adorno, Theodor W. "Zum Klassizismus von Goethes Iphigenie." Noten zur Literatur. Ed. Rolf Tiedemann. Frankfurt am Main: Suhrkamp, 1984: 495-514; Hohendahl, Peter Uwe. „A Precarious Balance: Adorno and German Classicism.“ New Literary History: A Journal of Theory and Interpretation 42.1 (2011): 31-52; Henkel, Arthur. "Die 'verteufelt humane' Iphigenie." Euphorion 59 (1965): 1-17; Henkel, Arthur. "Iphigenie auf Tauris. "Das deutsche Drama vom Barock bis zur Gegenwart: Interpretationen. Ed. Benno von Wiese. Vol. 1. Düsseldorf: Bagel, 1958: 169-92.

${ }^{33}$ Erhart, Walter. "Drama der Anerkennung: Neue gesellschaftstheoretische Überlegungen zu Goethes Iphigenie auf Tauris." Jahrbuch der Deutschen Schillergesellschaft 51 (2007): 140-65.

${ }^{34}$ Schiller, Friedrich. Nationalausgabe. Ed. Julius Petersen and Gerhard Fricke. 43 Vols. Weimar: Hermann Böhlaus Nachfolger, 1943pp.

${ }^{35}$ Goethe, Johann Wolfgang. Sämtliche Werke: Briefe, Tagebücher und Gespräche [FA]. Ed. Dieter Borchmeyer. Vol. 5. Frankfurt am Main: Deutscher Klassiker-Verlag, 1988.
} 
Scythian Thoas by speaking the truth ${ }^{36}$ — has been assessed time and again as evidence of her autonomy. ${ }^{37}$

Yet the dramatic form of the play, which epically juxtaposes two plots that reciprocally comment and reflect on one another, precludes such a trite course of events that would lead from Orest to Iphigenie, from heteronomy to autonomy, and from religious magic to Enlightenment reason, from myth to modernity. Goethe worked out this form in the three prose versions of the play from 1779, 1780, and $1781 .^{38}$ No wonder that in the first performance in Weimar in 1779, Goethe himself played the role of Orest. Thus, in a letter to Goethe from 22 January 1802, Friedrich Schiller-the reader who puts his finger on the problem-clairvoyantly proposes the "Orestischen Scenen zu verkürzen” (Schiller 31: 92). Although Goethe particularly rewrites the entire fourth act when he transposes the play into blank verse in 1787, Iphigenie still remains a double drama that negotiates the institutions of the curse. But in this negotiation the different sides run askew to the characters and form a chiasmus: where we expect the autonomous Iphigenie, we find a character solidly anchored in myth; and where we see the heteronomous Orest, we discover that the religious institution of the curse is actually introjected into the subject.

Religious and secular paths intersect in Iphigenie auf Tauris. As Albrecht Koschorke argues, Goethe's play is most fundamentally about the "epistemological problems of human faith in the gods," 39 a faith which is also the precondition for the success or failure of the curse. In his tragedy Iphigenia in Tauris, Euripides already shows how communicative acts that require a religious institution are, by their very nature, prone to failure. ${ }^{40}$ At the end of the play, only a dramaturgi-

\footnotetext{
${ }^{36}$ Geisenhanslüke, Achim. "Geständnistiere: Zur Genese der Aufrichtigkeit in Goethes Iphigenie auf Tauris." Iphigenie von Euripides/Goethe: Krieg und Trauma in Nicolas Stemanns Doppelinszenierung am Thalia Theater Hamburg. Ed. Ortrud Gutjahr. Würzburg: Königshausen \& Neumann, 2008: 89-109.

${ }^{37}$ Neumann, Gerhard. "'Reine Menschlichkeit': Zur Humanisierung des Opfers in Goethes Iphigenie." Humanität in einer pluralistischen Welt? Themengeschichtliche und formanalytische Studien zur deutschsprachigen Literatur. Ed. Christian Kluwe and Jost Schneider. Würzburg: Königshausen \& Neumann, 2000: 219-36.

${ }^{38}$ Reinhardt, Hartmut: "Die Geschwister und der König: Zur Psychologie der Figurenkonstellation in Goethes Iphigenie auf Tauris." Johann Wolfgang Goethe. Lyrik und Drama. Neue Wege der Forschung. Vol. 1. Ed. Bernd Hamacher and Rüdiger Nutt-Kofoth. Darmstadt: Wissenschaftliche Buchgesellschaft, 2007: 171-88.

${ }^{39}$ „[...] epistemologische Problematik des menschlichen Götterglaubens.“ Koschorke, Albrecht. "Das Politische und die Zeichen der Götter. Zum Lied der Parzen in Iphigenie auf Tauris." Die Gabe des Gedichts. Goethes Lyrik im Wechsel der Töne. Ed. Gerhard Neumann and David Wellbery. Freiburg im Breisgau: Rombach, 2008: 143-59, here 155.

${ }^{40}$ Zimmermann, Bernhard. Spurensuche: Studien zur Rezeption antiker Literatur. Freiburg im Breisgau: Rombach, 2009: 91-101.
} 
cal trick is able to help: Athena saves the institution dea ex machina and does so more wrongly than rightly. Koschorke judges Iphigenie's manipulative behavior, which Goethe radicalizes, particularly harshly. The entire play is, he argues, a "parable about the usefulness of divine manifestations," ${ }^{\prime 1}$ at the center of which is the hermeneutics of divine signs - first of the oracle and, second of the curse. The oracle and curse refer to one another since the oracle of Apollo presents Orest with the prospect of lifting the curse, but the adventurous plot of the double drama is based on "[d]er Götter Worte" always remaining "doppelsinnig" (Goethe, FA 572, 613).

The curse of the Tantalids is present in all of the observed communicative situations. All the characters know the story and refer to the myth, which, as a symbolically generalized medium of communication, represents a success medium (Erfolgsmedium): ${ }^{42}$ the myth guarantees the improbable success of communication between Iphigenie and Thoas, Greek and Scythian, man and woman. In the third scene of the first act, Iphigenie, the priestess of Artemis, refers to this cultural narrative intending to prevent both further human sacrifices and her marriage to Thoas. She thereby uses the content of the "fremder Fluch" (Goethe, $F A 55784$ ) without cursing herself. Instead, she especially employs expositive utterances ("Ich bin aus Tantalus Geschlecht" (563, 306); "Ich bin es selbst, bin Iphigenie" $(567,430)$ ). These speech acts are characterized as such by a double bind. On the one hand, Iphigenie aggrandizes herself above Thoas through the revelation of her divine genealogy:

Iphigenie:

$[\ldots]$

Vernimm! Ich bin aus Tantalus Geschlecht.

Thoas:

Du sprichst ein großes Wort gelassen aus.

Nennst du Den deinen Ahnherrn, den die Welt

Als einen ehmals Hochbegnadigten

Der Götter kennt? Ist's jener Tantalus,

Den Jupiter zu Rat und Tafel zog,

An dessen alterfahrnen, vielen Sinn

Verknüpfenden Gesprächen Götter selbst,

Wie an Orakelsprüchen, sich ergetzten? (563-564, 306-14)

${ }^{41}$, „[... $]$ Parabel über die willkürliche Verwendbarkeit von Manifestationen des Göttlichen [...]." Koschorke. Das Politische und die Zeichen der Götter: 151.

${ }^{42}$ Luhmann, Niklas. Die Gesellschaft der Gesellschaft. Vol. 1. Frankfurt am Main: Suhrkamp, 1997: 202-05. 
Thoas is not only familiar with Tantalus, he also presents Tantalus as a narrator of stories that are analogous to oracles. Tantalus's ambiguous and intricately interwoven stories are as beautiful as oracles. Apparently Iphigenie has inherited from her apical ancestor the rhetorical and poetic talent she displays when she tries to deter Thoas with the description of a series of increasingly intense atrocities, which culminate in Atreus's infanticide and anthropophagy $(566,389)$. Although this friend of good stories turns away for a moment, the humane Thoas actually loves Iphigenie with no consideration for her status; it is this absolute love that he autonomously places above his faith by suspending the human sacrifices for his priestess as long as he wants to:

Iphigenie:

$[\ldots]$

Ich bin es selbst, bin Iphigenie,

Des Atreus Enkel, Agamemnons Tochter,

Der Göttin Eigentum, die mit dir spricht.

Thoas:

Mehr Vorzug und Vertrauen geb' ich nicht

Der Königstochter als der Unbekannten.

Ich wiederhole meinen ersten Antrag:

Komm, folge mir und teile was ich habe. (567, 430-36)

While Iphigenie refers to herself as a "Flüchtige" $(562,252)$ and a "verwünschtes Haupt" $(562,268)$, Thoas simply turns the tables by calling the curse a "Segen" $(563,283)$ and excusing Tantalus: "Unedel war er nicht und kein Verräter [...] So war / Auch sein Vergehen menschlich [...]" (564, 319-22). The performative force of the curse has no validity for Thoas; he apparently does not believe in the religious institution that lends it power. Thus, the relationship between the enlightened Greek and the unenlightened Scythian is also upended. The curse does not have any power over Thoas, yet it does have the force that language obtains through Iphigenie's irrational feminine desire. For this reason, Thoas shifts, in short, the institution from transcendence to immanence: not the gods, but the heart is the institution of the curse:

Thoas:

Es spricht kein Gott; es spricht dein eignes Herz.

Iphigenie:

Sie reden nur durch unser Herz zu uns. (568, 493-94)

This shift of the institution of the curse from the gods into language (of the heart) depends-from the characters' perspective-on Thoas's 
interpretation, and that means to some extent on his Enlightenment view. He fulfills the paradigm change that leads from myth to modernity. Although Iphigenie uses the narrative of the curse as a means of rhetorical manipulation, she is, of course, very distant from Thoas's modern position, which would grant her autonomy from the gods. ${ }^{43}$ Her manipulation stops short of the religious institution that imposes the curse. To speak of the curse, to employ it for one's own goals, does not entail breaking it. Rhetorical agency alone does not lift it. Instead, Iphigenie remains blindly imprisoned in her faith and with it in the world order that guarantees the curse. On the one hand, "[d] es größten Königes verstoßne Tochter" $(556,41)$ uses the curse to excuse the actions of her father Agamemnon since not he but rather an anonymous force ("Sie") wanted to sacrifice her. On the other hand, she attaches herself to the ancestral line of Tantalus. Only the goddess Artemis is able to lift the curse, which she has also done, and now Iphigenie serves her on Tauris.

Iphigenie:

$[\ldots]$

Sie lockten mit der Mutter mich in's Lager;

Sie rissen mich vor den Altar und weihten

Der Göttin dieses Haupt. - Sie war versöhnt;

Sie wollte nicht mein Blut, und hüllte rettend

In eine Wolke mich; in diesem Tempel

Erkannt' ich mich zuerst vom Tode wieder. (567, 424-29)

In addition to the first scene of the first act, the curse also serves as a symbolically generalized medium of communication in the scene of anagnorisis between Iphigenie and Orest in the first scene of the third act, where it makes communication between Iphigenie and a stranger possible. Iphigenie hopes to obtain information about the fate of her siblings from this stranger, whom she does not at first recognize as her brother:

Iphigenie:

Weh dir, unseliges Mycen!

So haben Tantals Enkel Fluch auf Fluch

Mit vollen wilden Händen ausgesät!

$[\ldots]$

Wie ist des großen Stammes letzter Sohn,

\footnotetext{
${ }^{43}$ Kramer, Olaf. "'Es spricht kein Gott, es spricht dein eignes Herz': Kommunikative Autonomie und rhetorische Typologie in Goethes Iphigenie." Jahrbuch Rhetorik 33 (2014): 114-30, here 127-30.
} 
Das holde Kind, bestimmt des Vaters Rächer

Dereinst zu sein, wie ist Orest dem Tage

Des Bluts entgangen? Hat ein gleich Geschick

Mit des Avernus Netzen ihn umschlungen?

Ist er gerettet? Lebt er? Lebt Elektra? (583, 967-981)

This communicative act between the siblings is successful since they reveal their identities to one another over the course of the scene ("Ich bin Orest!" (586, 1082); "Orest, ich bin's! sieh Iphigenien!" (589, $1173)$ ). But while the curse is lifted from Iphigenie, it is far from lifted from Orest, at least from her perspective, even after this talking cure. In the third scene, the priestess of Artemis thus once again calls on her gods to ask for her brother's redemption-that is, in the scene immediately after the vision of Hades in which Orest proclaims that he has been redeemed:
Iphigenie:
[...]
O laß den einz'gen spätgefundnen mir
Nicht in der Finsternis des Wahnsinns rasen!
Und ist dein Wille, da du hier mich bargst,
Nunmehr vollendet, willst du mir durch ihn
Und ihm durch mich die sel'ge Hülfe geben;
So lös' ihn von den Banden jenes Fluchs,
Daß nicht die teure Zeit der Rettung schwinde. (593, 1325-31)

The wonder of Orest's redemption is thus not the result of the talking cure; instead, it is solely thanks to the gods, whom she asks to bless him.

Iphigenie:

$[\ldots]$

O wenn vergoßnen Mutterblutes Stimme

Zur Höll' hinab mit dumpfen Tönen ruft:

Soll nicht der reinen Schwester Segenswort

Hülfreiche Götter vom Olympus rufen? (588, 1164-67)

Just as Iphigenie is not at all the autonomous subject, she is also not at all humane, as becomes clear in the fifth scene of the fourth act, which ends with the famous song of the Fates (Parzenlied). Before Iphigenie remembers the song, she refers again to the curse of the Tantalids, to which all of her family, apart from herself, is still subject:

Iphigenie:

$[\ldots]$

Soll dieser Fluch denn ewig walten? Soll

Nie dies Geschlecht mit einem neuen Segen 
Sich wieder heben? - Nimmt doch alles ab!

Das beste Glück, des Lebens schönste Kraft

Ermattet endlich! Warum nicht der Fluch? (604, 1694-98)

The only possible means against the curse is the force of her wish when she calls upon the Olympians, which again confirms the double form of magical speech acts. The speaker of the wish is the subject and object of the world order that equally establishes all the types of formulaic language: curse, blessing, and wish.

Iphigenie:

$[\ldots]$

$\mathrm{O}$ daß in meinem Busen nicht zuletzt

Ein Widerwillen keime! der Titanen,

Der alten Götter tiefer Haß auf euch,

Olympier, nicht auch die zarte Brust

Mit Geierklauen fasse! Rettet mich,

Und rettet euer Bild in meiner Seele!

Vor meinen Ohren tönt das alte Lied -

Vergessen hatt' ich's und vergaß es gern -

Das Lied der Parzen, das sie grausend sangen,

Als Tantalus vom gold'nen Stuhle fiel: $(605,1712-21)$

Koschorke emphasizes, on the one hand, the circular structure of this wish to possess certainty, which is directed toward divine but unreliable addressees. ${ }^{44}$ On the other hand, he calls attention to the triple framing of the song, which opens a paradigmatic series. The Fates sang the song to an old exiled man, as the song itself mentions in its sixth stanza. And Iphigenie knows of the song from her nurse, who used to sing it to Iphigenie and her siblings (1724-25); and now Iphigenie sings it, and sings of its previous performances, in a traumatic situation. Neither the Fates nor the nurse qualify, however, as reliable narrators. The declamation therefore emerges as a regression. ${ }^{45}$ That may well be true-in any case, Iphigenie functions as a structural substitute for both the wet nurse and the Fates, which is indicated when she joins the row of singers, forming a mythological paradigm.

Precisely because the song is composed, moreover, of logical and topological reflections, making it a microdouble of the communicative situation observed throughout Iphigenie auf Tauris, it does not lead Iphigenie to autonomy. "The decision for autonomy can only be made in an eccentric position, in the opening to the Other and in proximity

${ }^{44}$ Koschorke. Das Politische und die Zeichen der Götter: 155.

${ }^{45}$ Koschorke. Das Politische und die Zeichen der Götter: 156. 
to the Other-that is, where the decision loses the character of selfcertainty." ${ }^{46}$ This decision not only concerns Iphigenie but also Orest. That Iphigenie auf Tauris is a secretive Oresteia is apparent even in the structure of the play. Orest is, in fact, the only character who develops over the course of the play, while Iphigenie remains as wise or unwise as she was at the beginning. The moment when Orest's heteronomy turns into autonomy constitutes the climax of the third act, in which Goethe subjectivizes the curse of the Tantalids in the case of Orest.

In the meeting of the two siblings, which was analyzed from Iphigenie's perspective as a scene of anagnorisis, the melancholic Orest imagines the enforcers of the curse $(590,1228-32),{ }^{47}$ who remain invisible to everyone else. Like Euripides before him, Goethe psychologically interprets Orest's mythological consciousness. "[D]ie Ursache seines Zustands," writes Friedrich Schiller to Goethe on 22 January 1802, lies "bloß im Gemüth" (Schiller 31: 92). For Orest takes "das Amt der Furien auf [s]ich" (Goethe, FA 757), and thus introjects the curse so that the persecution of Orest merely has to do with intrapsychic "Zweifel" and "Reue" $(585,1061)$. In the confrontation with his sister, he constructs a series of names that closely connects Iphigenie with both Clytemnestra and the enforcers of the curse. In the verse version he says, "O laß dein Fragen und geselle dich / Nicht auch zu den Erinnyen" $(588,1148-49)$, while the prose version is even clearer: "Es ruft! Es ruft! So willst du mein Verderben! Hat eine Rachegottheit sich in dich verkleidet?" (175). Orest's melancholy is thus revealed to be a self-destructive narcissism: ${ }^{48}$ in the repetition of experience, Orest has the "Eindruck eines [ihn] verfolgenden Schicksals, eines dämonischen Zuges in [seinem] Erleben," ${ }^{\prime 9}$ as Sigmund Freud explains such experiences in Jenseits des Lustprinzips—they become a "Schicksalszwang." 50

Throughout the play, many attributions relate Iphigenie to Artemis; $;{ }^{51}$ as the priestess of Artemis, Iphigenie is to sacrifice Orest according

\footnotetext{
46" Die Entscheidung zur Autonomie kann nur in einer exzentrischen Position, in der Öfnung auf das Andere und in der Nähe des Anderen fallen, - also gerade dort, wo sie den Charakter der Selbstgewißheit verliert." Koschorke. Das Politische und die Zeichen der Götter: 158.

${ }^{47}$ Ekelund, Lena and Stefan Hermes. "Gerettete Königskinder: Orest, der Wahn und die Schwester(n) bei Goethe und Euripides." Iphigenie von Euripides/Goethe: 113-26.

${ }^{48}$ Geisenhanslüke, Achim. Johann Wolfgang Goethe, Iphigenie auf Tauris: Interpretation. Munich: Oldenbourg, 1997: 45.

${ }^{49}$ Freud, Sigmund. Gesammelte Werke. Ed. Anna Freud et al. Vol. 13. Frankfurt am Main: Fischer, 1999: 20.

${ }^{50}$ Freud. Gesammelte Werke. Vol. 13: 22.

${ }^{51}$ Reed. Iphigenie auf Tauris: 195.
} 
to Taurian custom, which would make her an enforcer of the curse. The Furies (Erinnyen), Artemis, and Iphigenie thus form a second mythological paradigm. Goethe may have known that Iphigeneía is a particular instantiation of the Aegean great goddess, who was considered to be both the priestess and the epiclesis of the chthonic, maternal Artemis according to the relevant entry in Benjamin Hederich's Gründlichem mythologischen Lexikon from $1770 .^{52}$ Karl Kerényi notes, moreover, that in Greek mythology, Iphigeneia is an epithet or even a substitute of Artemis. ${ }^{53}$ Thus, an association between Iphigenie and Artemis has a cultural basis. Orest's persecution thus climaxes in the so-called vision of Hades in the second scene of the third act. It is the climax because in this vision, as Emil Staiger has pointed out, Goethe assigns a place and genealogy to the destructive forces that he has installed in the ego.

Orest:

$[\ldots]$

Mit Fluch beladen stieg er herab.

Doch leichter träget sich hier jede Bürde:

Nehmt ihn, o nehmt ihn in euern Kreis! - (592, 1284-86)

Yet, like Iphigenie, Orest has had from the beginning an Enlightenment counterpart at his side, who questions the religious institution of the curse and copes with the old world order humanely. In the first scene of the second act, Pylades comments on the curse of the Tantalids: the son "erbt der Eltern Segen, nicht ihr Fluch" $(575,717)$. Orest's redemption from the curse, which "simply" happens after he faints, is motivated by rationalization and psychologization. ${ }^{54}$ For, on the stage of the subject, the curse does not have to be lifted; instead it can be "geheilt" (600, 1536 and 602, 1607), as Freud diagnoses in his Ansprache im Frankfurter Goethe-Haus: "In seiner vielleicht erhabensten Dichtung, der Iphigenie, zeigt uns Goethe ein ergreifendes Beispiel einer Entsühnung, einer Befreiung der leidenden Seele von dem Druck der Schuld, und er läßt diese Katharsis sich vollziehen durch einen leidenschaftlichen Gefühlsausbruch unter dem wohltätigen Einfluß einer liebevollen Teilnahme. ${ }^{55}$ Indeed, the institution of the heart thus replaces that of the gods, which is already anticipated in

\footnotetext{
${ }^{52}$ Hederich, Benjamin. Gründliches mythologisches Lexicon. Darmstadt: Wissenschaftliche Buchgesellschaft, 1996: 1363-66.

${ }^{53}$ Kerényi, Karl. Die Mythologie der Griechen. Vol. 2. Die Heroengeschichten. Munich: DTV, 1966: 258.

${ }^{54}$ Staiger. Goethe: 360-62.

${ }^{55}$ Freud. Gesammelte Werke. Vol. 14: 548; Port, Ulrich. Pathosformeln: Die Tragödie und die Geschichte exaltierter Affekte (1755-1886). München: Fink, 2005: 139-41.
} 
the figure of Thoas. By splitting Orest into an ego and the intrapsychic agent of the heart, which speaks to him and makes him speak, Goethe completes the subjectivization of the curse:

Orest:

$[\ldots]$

Laß mich zum erstenmal mit freiem Herzen

In deinen Armen reine Freude haben!

$[\ldots]$

Es löset sich der Fluch, mir sagt's das Herz.

Die Eumeniden ziehn, ich höre sie,

Zum Tartarus und schlagen hinter sich

Die ehrnen Tore fernabdonnernd zu.

Die Erde dampft erquickenden Geruch

Und ladet mich auf ihren Flächen ein,

Nach Lebensfreud' und großer Tat zu jagen. (594, 1343-64; our emphasis)

Rasch, for good reasons, votes for Orest's autonomy. ${ }^{56}$ In contrast to Iphigenie, who counts herself among the accursed-just as she is, inversely, included in the mythological enforcers of the curse-the no longer cursed Orest now reclaims the rhetorical agency that gives the curse its power by cursing himself. He is thus both the object and medium of the curse. He is the force that he addresses in the apostrophe below when he curses his "Leib" and with it the "Barbaren." Autonomy thus becomes manifest in the immanent force of language to curse, which presupposes a splitting of the self into a cursing and a cursed ego. Consequently, with his "Leib," Orest makes himself the authoritative medium of the curse:

Orest:

$[\ldots]$

Es stürze mein entseelter Leib vom Fels,

Es rauche bis zum Meer' hinab mein Blut,

Und bringe Fluch dem Ufer der Barbaren! (586, 1089-91)

Orest's rhetorical agency culminates in the question of interpretive sovereignty with regard to the curse of the Tantalids. It is well known that Goethe outdoes and fulfills the Euripidean tragedy by making the religious institution only become tangible in belated acts of interpretation. The interpretation of the oracle in the sixth scene of the fifth act makes the disempowerment of the gods possible and also marks

\footnotetext{
${ }^{56}$ Rasch, Wolfdietrich. Goethes 'Iphigenie auf Tauris' als Drama der Autonomie. Munich: Beck, 1979: 119.
} 
the switch from heteronomy to autonomy, from myth to modernity, in which there are no longer any "Götter und Geister" (Schiller 31: 92). With a "hermeneutic "coup," Orest manipulates the King of the Taurians, ${ }^{57}$ allowing the Greeks to leave the island unharmed. The truth of the matter, however, is that Orest does not manipulate Thoas, but rather convinces him of the correct meaning of the oracle. The basis is a "normal" disambiguation of the oracle, meaning that it contextualizes the oracle and presents itself as a correctio, a verdictive speech act. Accused by Thoas of looting cultural artifacts, Orest enlightens the enlightened prosecutor: "Das Bild, o König, soll uns nicht entzweien!" (Goethe, FA 617, 2107). The entire affair was an "Irrtum" $(617,2108)$, for which the ambiguous oracle is responsible:

Orest:

[...]

Um Rat und um Befreiung bat ich ihn

Von dem Geleit der Furien; er sprach:

"Bringst du die Schwester, die an Tauris Ufer

Im Heiligtume wider Willen bleibt,

Nach Griechenland; so löset sich der Fluch.” (617, 2111-15)

Due to the vagueness of the determinate articles, the oracle's utterance can have two meanings depending on the situational context: "die Schwester" can refer to either the statue or Iphigenie. In this sense, Orest explains to Thoas: "Wir legten's von Apollens Schwester aus" $(617,2116)$; that is, they both interpreted Apollo's sister to be the referent of "Schwester" in the oracle. But Apollo could have actually meant Iphigenie with "die Schwester"-and not the "Bild" of his own sister, the goddess Artemis. Thoas is convinced by this disambiguation: the cultic statue remains on Crimea and the Greeks are able to leave with the sister-"Lebt wohl!" $(619,2174)$. Although Orest proceeds rhetorically, he does not manipulate Thoas, but rather convinces him. He can convince him because both communicate outside of the world order that is established by the curse of the Tantalids; because they both face one another-to put it trenchantly-as moderns. This reading resolves the much-discussed lack of motivation for the play's conclusion. Why should two rational men not be in the position to arrive at an understanding? From this perspective, Thoas is the model of an Enlightenment politician. ${ }^{58}$ Yet this interpretation of the oracle is again turned on its head when Orest addresses Iphigenie after the correctio in a narratio that restores the oracle's ambiguity:

\footnotetext{
${ }^{57}$ Koschorke. Das Politische und die Zeichen der Götter: 153.

${ }^{58}$ Rasch. Goethes 'Iphigenie auf Tauris' als Drama der Autonomie: 99-116.
} 


\author{
Orest: \\ [...] Gleich einem heil'gen Bilde, \\ Daran der Stadt unwandelbar Geschick \\ Durch ein geheimes Götterwort gebannt ist, \\ Nahm sie dich weg, dich Schützerin des Hauses; \\ Bewahrte dich in einer heil'gen Stille \\ Zum Segen deines Bruders und der Deinen. (618, 2127-34)
}

First, by comparing Iphigenie with the divine image and, second, by placing the image in the temple of Artemis, Orest makes his sister into a cultic statue in personam. The verbs wegnehmen and bewahren suggest that the direct object is a possession. They do not normally take living beings—and especially not humans—as their objects, so the statement presupposes the objectification of Iphigenie. Orest thus plans to do the exact same with the cultic statue as Artemis did with Iphigenie when Agamemnon was about to sacrifice her: he plans to remove it from one place and store it in another. Orest's sister and Apollo's sister are thus interchangeable variables of one and the same action. In this way, Orest constructs a third mythological paradigm, making his and Apollo's sister substitutable at one and the same syntagmatic place of the oracle.

With regard to the ambiguity of the oracle, this means that Orest actually brings Artemis to Greece by bringing his sister with him. Consequently, Iphigenie remains imprisoned in the world order in which the gods reign. At the end of the play, Iphigenie also literally speaks a different language than Orest and Thoas. And the understanding between the two does not inspire any alternative faith in her; instead, she demands that Thoas bless the departure of the siblings. Iphigenie thus connects the curse with its direct opposite. Both the curse and the blesssing presuppose the same institution that Iphigenie believes in and embodies as the substitute of the goddess: "Nicht so, mein König! Ohne Segen, / In Widerwillen, scheid' ich nicht von dir" (618, 2152-53).

Moreover, the interpretation of the oracle constitutes the fulcrum that interconnects the two plots of this Beobachtungsspiel, the Iphigenie plot and the Orest plot. The relay of this interconnection is, in Goethe's Oresteia, the character of Orest. The chthonic, maternal imago of Artemis-Iphigenie depends on the perspectival consciousness of his character. Since this is the case, the interpretation of the oracle as a moment of "redemption" after the vision of Hades is, of course, more than questionable: such a mother-sister can recover her power at any time and turn against the ego in the Hades of the unconscious with all possible power and archaic cruelty. By psychologizing the 
curse, Goethe shifts its structure of repetition into the masculine, narcissistic subject, and concludes his "Schauspiel" with an epically elegant open end.

\section{Syntagmatic variations: Faust and Manfred}

"Welch ein verfluchtes Abenteuer!" (Goethe, Faust 453, line 11783). ${ }^{59}$ With this curse Mephisto sums up the dramatic plot of Goethe's Faust at the conclusion of the second part when Faust's soul is snatched away from him. In this paper we take Mephisto seriously and consider how Faust's journey through the great and small world truly is under a curse. Up through the most recent scholarship, Faust's curse in the second Studierzimmer scene has been interpreted as a mere sign of his despair following his failed suicide attempt. ${ }^{60}$ But the significance of the curse is much greater than that. Faust may not be under a curse, but he does become a cursing subject who levels the triadic structure of curses and ceases to recognize any institution of the curse beyond the subject. Cursing is thereby on its way to being institutionalized within the subject, though admittedly before this institution becomes psychologized. One searches in vain for the psychological parts of the self in Faust's curse, but not for the traditional canon of values and its authorities. Taking this radical curse seriously as a performative speech act means placing it in a series with two other speech acts: the wager and the pact. The wager between the Lord and Mephisto in the Prolog im Himmel establishes the conditions for both Faust's curse in particular and the entire dramatic plot more generally. The wager refers, as is well known, to the Book of Job ${ }^{61}$ but it intensifies the configuration from the Old Testament. In Goethe, Faust has a double function: he is both the object and stakes of the wager. As an exercitive speech act, every wager is a contract that establishes a course of action based upon an extra stipulation. ${ }^{62}$ The speaker only commits himself to the course of action if this stipulation is met. By accepting the wager, the addressee usually commits to a reciprocal course of action if the stipulation is not met. The wager is valid after

\footnotetext{
2003.

${ }^{59}$ Goethe, Johann Wolfgang. Faust. Ed. Albrecht Schöne. Frankfurt am Main: Insel,

${ }^{60}$ Krings, Marcel. “'Du hast sie zerstört, die schöne Welt': Antimoderne und Idealismuskritik in Goethes Faust I." Goethes Faust $I^{‘}$ zwischen Tradition und Modernität. Ed. Philippe Wellnitz. Strasbourg: Presses Universitaires de Strasbourg, 2010: 111-32; Schmidt, Jochen. Goethes Faust. Erster und Zweiter Teil. Grundlagen - Werk - Wirkung. Munich: Beck, 1999: 95-108.

${ }^{61}$ Schrader, Hans-Jürgen. "Modell des Menschen: Hiob im Goetheschen Faust." Colloquium Helveticum 34 (2003): 159-91.

${ }^{62}$ Austin. How to do things with Words: 155-157.
} 
the exchange of the declarations of intent. Both partners of the wager thus commit to a course of action, but only one will have to fulfill it in the end. In the Prolog im Himmel, Faust appears at two points in the exercitive speech act of the wager, with which the Lord commits himself-of course not without a much-discussed little loophole ${ }^{63}$ to a course of action. Faust is the stakes, which the Lord has at his disposal, and he is also the stipulation that determines which of the two will win the bet. The wager of the Prolog thus has an asterisk not only because it is made between seemingly asymmetric parties, but also because the logic of speech-act theory shifts the focus to Faust.

A curse encroaches on the constellation of the wager due to the all-too-obvious allusions to Job. The biblical Satan will win the Old Testament wager if Job renounces God with a curse (Job 1:11) ${ }^{64}$ which God declares to be impossible. Even when Job later curses the day of his birth (Job 3:3-10), and thus at least indirectly condemns God as his creator, his wife cannot convince him to curse God and die (Job 2:9).$^{65}$ In contrast, Faust curses extensively and, in one sweeping blow, he not only imprecates the day of his birth but also all of creation ${ }^{66}$ With the curse, the character of Faust asserts himself and breaks free from the framework of the Prolog's heavenly wager, though he continues to refer to it all the same:

\section{Faust:}

Wenn aus dem schrecklichen Gewühle

Ein süß bekannter Ton mich zog,

Den Rest von kindlichem Gefühle

Mit Anklang froher Zeit betrog:

So fluch' ich allem was die Seele

Mit Lock- und Gaukelwerk umspannt,

Und sie in diese Trauerhöhle

\footnotetext{
${ }^{63} \mathrm{On}$ the preconditions of the wager, and especially on verses $315-17$, see Arens, Hans. Kommentar zu Goethes Faust I. Heidelberg: Winter, 1982: 49.

${ }^{64}$ The King James Version translates this explicitly as a "curse," while the Luther edition (Basel 1772) used by Goethe and consulted by Albrecht Schöne in his commentary renders it as follows: "er wird dich ins angesicht segnen? <ironisch im gegenteiligen Sinne gemeint." Schöne, Albrecht. Kommentare: Goethe Faust. Frankfurt am Main: Insel, 2003: 171 .

${ }^{65}$ Vette, Joachim: "Hiobs Fluch als thematische Klammer." Das Buch Hiob und seine Interpretationen: Beiträge zum Hiob-Symposium auf dem Monte Verità vom 14.-19. August 2005. Ed. Thomas Krüger et al. Zurich: Theologischer Verlag, 2007: 231-39, here 237-38. On the differences between the curse in the Book of Job and Faust's imprecation of creation, see Dumont, Altrud. "Faust - ein Urenkel Hiobs? Zum Verhältnis von Transformation und Abstoßung." Kreuzwege: Transformationen des Mythischen in der Literatur. Ed. Dietmar Jacobsen. Frankfurt am Main: Peter Lang, 1999: 123-44, here 124-28.

${ }^{66}$ Schings, Hans-Jürgen. "Faust und der dritte Schöpfungstag." Deutsche Vierteljahrsschrift für Literaturwissenschaft und Geistesgeschichte 88 (2014): 439-67, here 463.
} 
Mit Blend- und Schmeichelkräften bannt!

Verflucht voraus die hohe Meinung,

Womit der Geist sich selbst umfängt!

Verflucht das Blenden der Erscheinung,

Die sich an unsre Sinne drängt!

Verflucht was uns in Träumen heuchelt,

Des Ruhms, der Namensdauer Trug!

Verflucht was als Besitz uns schmeichelt,

Als Weib und Kind, als Knecht und Pflug!

Verflucht sei Mammon, wenn mit Schätzen

Er uns zu kühnen Taten regt,

Wenn er zu müßigem Ergetzen

Die Polster uns zurechte legt!

Fluch sei dem Balsamsaft der Trauben!

Fluch jener höchsten Liebeshuld!

Fluch sei der Hoffnung! Fluch dem Glauben,

Und Fluch vor allen der Geduld! (Goethe, Faust 73, 1583-1606)

The form of this all-in-one curse can be quickly described. It consists of twenty-four verses that can be divided into three semantic units, each containing eight verses. Each verse has four stressed syllables and begins with an anacrusis; the cross rhyme alternates strictly so that every other verse ends hypercatalectically with an unstressed syllable, followed by the unstressed first syllable of the next verse. Thus, of all stanzaic forms, Faust curses in the most common form of the German Enlightenment, which, furthermore, goes back to the sixteenth-century hymn (Kirchenlied) ${ }^{67}$ Goethe's Faust most prominently uses the same stanzaic form in the Prolog im Himmel, where the Archangels glorify the Lord by praising creation. With this intratextual reference, the praise and destruction of God's creation are shown to be directly related to one another on a formal level, and they refer, moreover, to the actual object of the wager: as the object of the wager, Faust should substitute for creation in its entirety, but he is also simultaneously the prize that Mephisto will receive if he successfully perverts the praise of creation through the seduction of Faust. In Faust's curse there is an unmistakable, though not at all metrically supported, element of acceleration, amplification, and intensification, ${ }^{68}$ leading Albrecht Schöne to call it

\footnotetext{
${ }^{67}$ Frank, Horst Joachim. Handbuch der deutschen Strophenformen. Tübingen and Basel: Francke, 1993: 649-53.

${ }^{68}$ Significantly, these elements are also present in the Archangels' praise of creation, especially in the dialogue of Gabriel and Michael. See Anderegg, Johannes: "Schöpfungslob und Himmelfahrt: Goethes 'Faust' und die Geschichte Hiobs." Jahrbuch des Freien deutschen Hochstifts. Ed. Anne Bohnenkamp. Tübingen: Niemeyer, 2007: 171-97, here $175-77$.
} 
a "curse avalanche" due to both its rhythm and content. ${ }^{69}$ With ever greater haste and, at the end, maximally condensed with anaphoras, Faust imprecates a canon of values that at first appears to be assembled quite arbitrarily; but a closer reading reveals a logic that first relates back to the wager from the Prolog im Himmel, and, second, becomes binding for the further course of the plot: the pact-wager of the Studierzimmer and the end of the play.

The curse is linked to Faust's preceding failed suicide attempt, and, with an ambiguous conjunction, it substitutes for the suicide as another form of sacrilege, though through words instead of actions $(444,11409)$. The ambiguity is displayed in the conjunction wenn, which can either be read as a concessive conjunction in the sense of although or as a causal conjunction in the sense of because. This ambiguity is structurally definitive for the curse because it triggers the polarity of the cursed objects. The text accordingly begins with an announcement before it enumerates the actual objects of the curse: everything that the soul associates with a reality discredited as a "Trauerhöhle"-that is, all the subjective connections between the I and the world-becomes the object of the curse that follows. The curse is thus a radical negation of the world and therefore, in the context of the Prolog im Himmel, of creation. The second part then juxtaposes oppositions according to the law of polarity: the spirit and senses are just as accursed as immaterial dreams and material possessions. Finally, in the first four verses of the third part, Faust imprecates money in the form of Mammon, which-in contrast to the possessions of the preceding semantic unit-is, in itself, ambivalent and therefore occupies the most space in Faust's curse. Mammon represents, as Adelung's dictionary informs us, ${ }^{70}$ not only legendary wealth but also an insatiable desire that instigates both bold deeds and idle delight. This refers most directly to the tragedy's sequel where Faust enters in the first act as Plutus, the god of wealth $(234,5569)$. But before it can come to that, Faust must first execrate wine as a religious balsam and then curse the Christian cardinal virtues-love, hope, and faith-in reverse order to the First Epistle to the Corinthians (1. Cor. 13:13). The end of this fatal cascade is formed by "Geduld," which, on the one hand, recalls the First Epistle to the Thessalonians with its formulation "patience of hope" (1. Thess. 1:3). On the other hand, "Geduld" functions as the motor of Faust's striving (Streben) and so

\footnotetext{
${ }^{69}$ Schöne. Kommentare: 256.

${ }^{70}$ Adelung, Johann Christoph. Grammatisch-kritisches Wörterbuch der Hochdeutschen Mundart. Vol. 2. Leipzig, 1796: 42-43.
} 
can be understood as the opposite of acedia (the indolence of the heart) ${ }^{71}$ from which he suffers and so imprecates here particularly sharply. ${ }^{72}$ Faust certainly does not exclude himself from this cascade of curses and with "Geduld" he also imprecates the putative prototypical attribute of Job. ${ }^{73}$ Consequently, Faust is not hunted by the Furies or by religious institutions, but rather only by himself; the curse has its roots within the subject.

It is for this reason that Faust does not need an authority, and definitely not a god, who would guarantee his curse. He does not apostrophize any power that would substantiate the curse other than himself. This goes so far that Faust switches in the middle of the curse from the first-person singular into the first-person plural and universalizes his experience. Furthermore, the curse is the systematic destruction of meaning that would be guaranteed by a third authority. Thus, with this curse as a negative confession, Faust not only destroys the Christian canon of values; he also sets himself as a subject so radically that the fulfillment of the curse is only substantiated by the subject itself. The imprecation of creation thereby becomes a curse of subjectivity, which does not exclude the subject itself. Subjectivity is both the object and subject of the curse: that is, it grounds the curse and is cursed (both by the very constraints that define the curse in the original wager from the Prolog im Himmel and in the curse itself). Within this structure, Faust destroys the "schöne Welt," as the invisible choir of spirits laments directly after the curse (Goethe, Faust $73,1609) .{ }^{74}$ But Faust's curse does not bring forth the destruction of the world without also demanding that it be rebuilt, a demand for a "Neuen Lebenslauf" $(74,1622)$. In this way, the curse sets the stage for the devil's pact that follows it. Since it applies above all to the "Seele" $(73,1587)$, it is, in its radical negation, not only a substitute for the suicide attempt, it also specifically refers to the double function of Faust in the wager between Mephisto and the Lord, where Faust's soul represents Mephisto's ultimate prize.

Faust's curse does not at all indicate, however, that Mephisto has won the bet, as the reference to Job could suggest. On the contrary,

\footnotetext{
${ }^{71}$ Wulf, F. "Trägheit." Lexikon für Theologie und Kirche. Ed. Josef Höfer and Karl Rahner. Vol. 10. Freiburg: Herder, 1965: 302-03.

${ }^{72}$ Schings. Faust und der dritte Schöpfungstag: 464; Wellbery, David E. Reflexion tragischer Form in Goethes 'Faust.' Talk at the Goethe-Nationalmuseum (Weimar) during his Meisterkurs "Goethes Poetik der Form." 25 August 2015.

${ }^{73}$ Laan, J. M. van der. Seeking Meaning for Goethe's Faust. London and New York: Continuum, 2007: 38-44.

${ }^{74}$ On the musical elements, see Hartmann, Tina. Goethes Musiktheater: Singspiele, Opern, Festspiele, 'Faust.' Tübingen: Niemeyer, 2004, 367-68; Schmidt. Goethes Faust: 139.
} 
the curse is the starting point for Faust's journey through the great and small world of the drama. A further speech act is required prior to the journey-namely, the pact, which is no less beset with stipulations and yet still depends on the curse. It is only after the destruction of the world with all its semantic relations that Faust becomes, as Jochen Schmidt notes, "ripe for the devil." 75 Mephisto notices this immediately and offers the appropriate contract $(75,1656-59)$. Yet Faust still cannot be so easily persuaded to sign the devil's pact. He is skeptical of whether Mephisto has anything at all to offer and is only convinced of the pact by the paradoxical "Schätzen" $(76,1689)$ and the offer of "was Gut's in Ruhe [zu] schmausen" $(76,1691)$. Precisely this last point is especially decisive because Faust uses it to turn the pact into a wager. Mephisto is required to realize one aspect of his catalogue of obligations as the condition upon which Faust will have to fulfill his side of the pact. This doubling within the second wager thus mirrors the double function of Faust in the first wager from the Prolog, where he is simultaneously the prize and the object. Faust's inner state of mind, manifest in the famous speech act "Verweile doch! du bist so schön!" $(76,1700)$, is also the criterion for Mephisto to win the wager. This speech act, which delivers Faust's soul to the devil, is the flipside of the curse, and it rescinds its own radical negation of the curse by taking up accursed Geduld and expressing a self-sufficiency that was unthinkable after the curse $(76,1695)$. In the structure of the curse, the "Verweile doch!" thus has the function of a blessing, albeit inverted, which terminates the "Taumel" $(78,1766)$ of the journey through the world and signals the end of the subjectivity guaranteed in the curse. This curse of subjectivity reveals itself in the path of destruction that Faust leaves everywhere behind him on his journey through the world; it is, however, also condition of the curse. The curse consequently has already changed Faust even before the pactwager with Mephisto: from a melancholic and suicidal scholar into an almost nihilistic subject. Nevertheless, the curse is not at all a sign of powerlessness: ${ }^{76}$ it is, rather, the powerful positing of the subject. In contrast, Mephisto remains merely "hiobsartig" $(453,11809)$ at the end when he imprecates the choir of angels $(453,11816)$ when it abducts the wager's prize: Faust's soul. For after the "Verweile doch" $(446,11582)$, the Lord seemingly intervenes again into the plot in the figure of the choir and derives redemption from the curse of Streben.

\footnotetext{
${ }^{75}$ Schmidt. Goethes Faust: 106.

${ }^{76}$ Brüning, Gerrit. "Die Wette in Goethes Faust." Goethe Yearbook 17 (2010): 31-54, here 40. On the difference between the power and powerlessness of curses, see Dorschel. Entwurf einer Theorie des Fluchens: 174.
} 
In comparison to Faust: Eine Tragödie, Goethe's partial translation of Lord Byron's dramatic poem Manfred clearly intensifies the curse of subjectivity by psychologizing the institution of the curse. As is well known, Lord Byron's texts exercised great influence on Goethe; ${ }^{77}$ the Goethe-Handbuch even groups Byron with Herder and Schiller as the three contemporaries that were most significant to his work. ${ }^{78}$ Goethe's selective translation of Manfred evidences, moreover, a reciprocal influence between the two. ${ }^{79}$ In the translation, Goethe reacts to Byron's Manfred, which is itself a radicalization of the epistemological aporias from Faust (Goethe, MA 11.2: 293-96) ${ }^{80}$ In addition to the first twelve verses of the drama, a central monologue of the protagonist, and an excerpt from the fourth scene of the second act, Goethe most prominently translates the curse that concludes the first scene of the first act. This curse is spoken by an abstract voice after Manfred summons-as a disproportionately successful revenant of Faust-a whole seven spirits and all the elements. At the same time, Manfred is already explicitly under a curse before the incantation:

Manfred:

$[\ldots]$

Since that all-nameless hour. I have no dread,

And feel the curse to have no natural fear,

Nor fluttering throb, that beats with hopes or wishes,

Or lurking love of something on the earth.- (Byron 53-54, lines 24-27) ${ }^{81}$

This curse is not tied to any authority beyond the subject, who, significantly, also "feel[s] the curse" of, paradoxically, not feeling anything: it is thus a curse of apathy that leaves only the curse itself to be felt. Consequently, the hour of malediction does not have a name, is "all-

${ }^{77}$ Hewitt, Ben. Byron, Shelley, and Goethe's Faust: An Epic Connection. London: Legenda, 2015 .

${ }^{78}$ Boyle, Nicholas. "Byron, George Gordon Noel, Lord." Goethe-Handbuch. Vol. 4.1: 145-49, here 148 .

${ }^{79}$ In particular, Evi Zemanek has recently examined Goethe's translations from Manfred, but she does not investigate the curse in Faust: Eine Tragödie. See Zemanek, Evi. "'Falsche Spiegelung'? Spekulation, Projektion, Identifikation. Goethes Übertragungen aus Byrons Manfred und Don Juan im Zeichen einer Re-Formierung des tragischen Helden.” Annäherung - Anverwandlung - Aneignung: Goethes Übersetzungen in poetologischer und interkultureller Perspektive. Ed. Markus May. Würzburg: Königshausen \& Neumann, 2013: 163-86.

${ }^{80}$ Goethe, Johann Wolfgang. Sämtliche Werke nach Epochen seines Schaffens: Münchner Ausgabe [MA]. Ed. Karl Richter. 21 Vols. Munich: Hanser, 1998; Jackson, Emila A. Bernhard. "Manfred's Mental Theater and the Construction of Knowledge." Studies in English Literature, 1500-1900 47.4 (2007): 799-824, here 800-801; Wesche, Ulrich. "Goethe's Faust and Byron's Manfred: The Curious Transformation of a Motif." Revue de Littérature Comparée 50 (1976): 286-90.

${ }^{81}$ Byron, George Gordon. The Complete Poetical Works. Ed. Jerome J. McGann. Vol. 4. Oxford: Clarendon Press, 1986. 
nameless," and thereby also evades the subject. The subsequent summoning of spirits is not only a reaction to this curse, but also needs the curse: "By the strong curse which is upon my soul" $(54,47)$. It is only now, in the third attempt, that the summoning of the powerful spirits works, but it does not serve its purpose of freeing Manfred from the curse. He pleads for "Forgetfulness" (57, 136), "Oblivion, self-oblivion" $(58,144)$, but the spirits cannot offer that because they are immortal and eternal, and, for that reason, are not conscious of time. Spirits neither die nor forget. Before he subsequently breaks off the incantation, Manfred demands to see the spirits in their own true forms. But these forms do not exist; the spirits are only formless elements. The seventh spirit, the spirit of fate, appears to him as a beautiful female figure, presumably his dead beloved. But when he tries to embrace it, he falls to the ground unconscious and becomes the object of the subsequent curse.

In Goethe's translation, this curse has a distinctly different form than in the original. Goethe adjusts two aspects. First, he frames the passage differently, and, second, he noticeably intensifies the dramatic climax in the sixth stanza. For the seven stanzas are actually not at all about a curse. While a paratext in the English original refers to the passage as an "incantation," thus suggesting connections to the conjuration scene in Faust, ${ }^{82}$ Goethe titles the passage "Bannfluch" and thus shifts its meaning: it is no longer about an incantation, but rather about a curse that expels its object from a-usually religious, but here moral-community. ${ }^{83}$ This significantly changes the interpretation of the framed verses.

But before we can take a closer look at this change, we must analyze the framed verses. For Goethe's translation focuses on two things with respect to form. First, it attempts to preserve the metrical structure of the original as much as possible. Goethe's translation is accordingly composed of seven acephalous ten-verse stanzas that string together four stressed syllables and end stressed or unstressed with irregular cadences. Second, Goethe tries to maintain the semantics of the ends of verses by leaving most of the words that are at the end of a verse in the original in the same position in his translation. In doing so, problems arise with syntax and rhyme. While the syntax is adapted accordingly, Goethe abandons the end rhymes; he does not employ the rhyme pattern of the original. Moreover, he deviates from Byron's meter at a crucial point: in the sixth stanza-the undisputable climax

\footnotetext{
${ }^{82}$ Zemanek. "Falsche Spiegelung": 170.

${ }^{83} \mathrm{Grimm}$ and Grimm. Deutsches Wörterbuch. Vol. 1: 1114.
} 
of the curse ${ }^{84}$ - Goethe breaks with the meter of the original in every single verse. Why this emphasis on the sixth stanza?

To answer this question, we must briefly investigate the function of the curse, or rather the "incantation." As already mentioned, Manfred pleads for forgetting, specifically self-forgetting, in the great summoning of the introductory scene. He omits, however, the object of this forgetting; it is inexpressible: "Ye know it, and I cannot utter it" (58, 138), he says to the summoned spirit when asked for his desires. In the curse, and this is our thesis, the psychological parts of the self return as a curse of memory, from which Manfred cannot free himself, but whose content he also cannot express consciously. For Manfred is not primarily damned for his deeds, but rather above all for the psychological parts of his self, as the fifth stanza makes explicit: his false tears, the blackest blood of his heart, and his poisonous smile-the worst poison that comes from Manfred's lips. Those are the means used in Manfred's curse that turn against him. This structure is intensified in the sixth stanza, where Manfred's characteristics directly become the object of the appeal and replace a third power-in addition to the curser and the accursed-in the apostrophic structure of the curse. The appeals culminate in the highest form of the curse, which again depends on an incantation as demonstrated in the sixth stanza:

Bei Deiner kalten Brust, dem Schlangenlächeln, By thy cold breast and serpent smile,

Der Arglist unergründlichem Schlund, By thy unfathom'd gulfs of guile,

Bei dem so tugendsam scheinenden Auge,

Bei der verschlossenen Seele Trug,

Bei der Vollendung Deiner Künste,

Dem Wahn, Du tragest ein menschliches Herz,

Bei Deinem Gefallen an Anderer Pein, By that most seeming virtuous eye,

By thy shut soul's hypocrisy; By the perfection of thine art Which pass'd for human thine own heart;

By thy delight in others' pain,

Bei Deiner Cains-Bruderschaft

Beschwöre ich Dich und nötige

Dich selbst Dir eigene Hölle zu sein!

(Goethe, MA 13.1: 473)

And by thy brotherhood of Cain, I call upon thee! and compel Thyself to be thy proper Hell! (Byron 61, 242-51)

\footnotetext{
${ }^{84}$ Where Byron bends the meter without breaking it by beginning every verse with an anacrusis and uniformly arranging the otherwise irregular verse ends with a stressed syllable, Goethe falls back, like in Faust, on a different, relatively unadorned and rare stanzaic form of the sixteenth-century hymn. On the stanzaic form of the hymn see Frank. Handbuch der deutschen Strophenformen: 708-09. The meter-iambic tetrameter with rhyming couplets-belongs, however, to the most frequent forms, especially in English. See Alden, Raymond Macdonald. English Verse. New York: Henry Holt, 1926: 160-73.
} 
In the last verse of this stanza, Goethe deviates from his rule not to change the ends of verses semantically. "Hell" is displaced from the end into the middle of the verse. Furthermore, it is also moved into the character, namely through the "Beschwöre ich," a specifying translation of "call upon." The incantation, which Goethe removes from the paratext, thus appears of all places in the center of the "Bannfluch" and displays once again Goethe's inversion of speech acts. While Manfred still relies on the curse for summoning spirits, in Goethe's translation it is now the curse that uses an incantation of all the things to seal Manfred's fate. This movement into the character should be taken seriously and shows that Goethe certainly recognized how Manfred pursues a psychologization and internalization of his Faust. This internalization is on display even in the verse structure of the "Bannfluch." At the same time, the curse remains ambiguous, just like the character's end.$^{85}$ For, in contrast to Faust, Manfred is not saved. If one only takes outer events into account, his fate remains just as much in the dark as his end is unmotivated. However, if one considers the psychology of the character, which the curse so potently summons, then his end is everything but unmotivated. The curse accordingly functions not as a prophecy that is fulfilled in the course of the drama on the level of plot, but rather as the establishment of an inner life that determines the character and the progress of the plot.

Beyond that, the transformation that Goethe undertakes with the framing of the "Bannfluch" is not only displayed in the title. In contrast to the short review, into which Goethe inserts his translation from the second scene of the second act and which is published in Über Kunst und Altertum in 1820, he only frames the "Bannfluch" with an article about Justus Möser and superstition. This text, published in 1823 also in Über Kunst und Altertum, is at first entirely devoted to the historian. The occasion was the announcement that further installments of Möser's Osnabrückische Geschichte were to be printed from the unpublished manuscripts. To illustrate his esteem, Goethe offers a loose citation of Möser that bears the heading "Über den Aberglauben unserer Vorfahren" (Goethe, MA 13.1: 470), which he then also comments on positively. In this text, superstition is not primarily harmful and not at all an expression of ignorance in unenlightened ages. In the form of "belehrende[n] Fabeln" (470), it is, on the contrary, even useful and above all contributes to the moral development of "Kindern," especially of "eitlen Mädchen" and "Gesinde" (470).

\footnotetext{
${ }^{85}$ McVeigh, Daniel M. "Manfred's Curse." Studies in English Literature, 1500-1900 22.4 (1982): 601-22, here 606-07.
} 
As a "Poesie des Lebens" (471), superstition is excusable and even useful in the form of frommen Fabeln with their angels and devils. To fight superstition means to guard onself against "Zauberstricke[ ]," "die sich immer stärker zusammenziehn, jemehr man sich gegen sie sträubt" (471). Goethe accordingly announces his translation of the "Bannfluch" as a "wahres Muster, wo die tiefsten sittlichen Gefühle unter psychischer Form sich in Aberglauben verwandeln, durch dessen Darstellung der Dichter sich selbst so vorsätzlich als ungläubig Schauder zu erregen trachtet" (471). In Byron's Manfred, there are admittedly few traces of deep moral feelings that turn into superstitions and are quasi-cathartically made innocuous in a program of moral education. On the contrary, the curse is intensified instead of weakened in Goethe's translation through the techniques of the sixth stanza, and the downfall of the protagonist appears, as opposed to the second part of Faust, as everything but improbable. The power of the curse remains unabated on the level of poetic articulation, despite the fact that Goethe tries to exorcize it through the essay on superstition in early modernity. Goethe's recognition of the true scandal of Manfred points to a deliberate ellipsis beyond the curse. For, when Manfred sees his beloved Astarte again in the fourth scene of the second act, Goethe's fragmentary translation tellingly skips over the twenty verses that hint at incest between Astarte and Manfred. ${ }^{86}$ At the mere intimation of incest-still the mythological short cut to blood revenge before its psychologization-even the label of superstition and its power are no longer of any help. Despite all its framings, this curse cannot be rendered harmless.

University of Zurich

Translated by Anthony Mahler

${ }^{86}$ Zemanek. "Falsche Spiegelung“: 166. 